\title{
THE RELATIONSHIP BETWEEN WORKING PERIOD OF BATIK CRAFTSMEN AND INCIDENT OF CARPAL TUNNEL SYNDROME
}

\author{
Subandi ${ }^{1}$, Diah Kurnia Mirawati ${ }^{1}$, Stefanus Erdana Putra ${ }^{2}$, Muhammad Hafizhan ${ }^{3}$, Wahyu Agung Susilo ${ }^{4}$, Rivan Danuaji ${ }^{1}$ \\ Correspondence: stefanuserdanaputra@gmail.com \\ ${ }^{I}$ Teaching Staff Department of Neurology Faculty of Medicine Sebelas Maret University, Surakarta, Indonesia. \\ ${ }^{2}$ Research Assistant Department of Neurology Faculty of Medicine Sebelas Maret University, Surakarta, Indonesia. \\ ${ }^{3}$ Medical Clerkship Faculty of Medicine Sebelas Maret University, Surakarta, Indonesia. \\ ${ }^{4}$ Resident Department of Neurology Faculty of Medicine Sebelas Maret University, Surakarta, Indonesia.
}

\section{Article History:}

Received: April 1, 2020

Accepted: June 15, 2020

Published: July 1, 2020

\section{Cite this as:}

Subandi, Mirawati DK, Putra SE, Hafizhan M, Susilo WA, Danuaji R. The relationship between working period of batik craftsmen and incident of carpal tunnel syndrome. Malang Neurology Journal; 2020.6:73-76. http://dx.doi.org/10.21776/ub.mnj.202 0.006 .02 .5

\section{ABSTRACT}

Background: Carpal Tunnel Syndrome (CTS) is the most common mono-neuropathy caused by median nerve entrapment on the wrist. Major risk factor of the CTS is repetitive use of the hand, whether from occupational activities or hobbies. One of the most frequent occupation affected with CTS is the batik craftsmen.

Objective: To investigate the relationship between working period of batik craftsmen with the incident of CTS at Kampung Batik Tulis Laweyan.

Methods: Participants of this cross-sectional study were 30 batik craftsmen from Kampung Batik Tulis Laweyan who met the inclusion and exclusion criteria. They were classified into two groups based on working period (less or more than five years), clinically examined, and underwent the Nerve Conduction Velocity studies. Bland's classification was administered for grouping the nerve injury. Spearman correlation test was performed to investigate the correlation between working period and incident of CTS.

Results: There was a significant medium positive correlation between working period and nerve injury based on Bland's classification $(\mathrm{r}=0.559 ; \mathrm{p}=0.013)$. While the chief complaints were also correlated with the working period, the association was not statistically significant $(\mathrm{p}=0.355)$.

Conclusion: This research suggests an association between the incident of CTS and longer working period in batik craftsmen.

Keywords: Carpal tunnel syndrome, median nerve neuropathy, batik craftsmen

\section{Introduction}

Carpal Tunnel Syndrome (CTS) is one of the most popular peripheral nerve disorders found in daily life due to the narrowing process of carpal tunnel caused by fascial edema of the tunnel or abnormalities of the hand bones. ${ }^{1}$ CTS is defined as weakness of the hand which happens in the median nerve distribution area. The median nerve originating from brachial plexus will pass through the carpal tunnel when going down from the forearm to the hand. ${ }^{2}$

CTS can commonly be found in general community or among industrial workers. The prevalence is around 50 cases per 1000 subjects in general population. The National Health Interview Study (NHIS) estimates the prevalence of CTS was $1.55 \%$. As one of the three most common diseases of Cumulative Trauma Disorder (CTD) group in the upper limb, the global prevalence of CTS in 2000 was $40 \% .^{3}$ International Labor Organization (ILO) report showed that CTS was almost always found in every case of occupational diseases in several countries. Even in China, in 2010 there was an increase in the number of cases of CTS due to work by approximately $30 \%$ compared to $2001 .^{4}$ The prevalence of CTS incidents in Indonesian workers is not yet known because there are no surveys conducted. However, a national study that was conducted in populations with high-risk occupations of the wrist and hand, reported a CTS prevalence of $5.6 \%$ to $15 \% .^{5}$

The high prevalence rate followed by high costs (medical treatment, rehabilitation, compensation for lost work hours, initial pension costs, also training for new workers) makes CTS a major problem in the field of employment. ${ }^{6}$

Batik industry in Surakarta, one of big cities in Indonesia, is capable of absorbing large numbers of workers from the community. It can be seen from the existence of several markets that sell batik, shops, or tourist destinations such as Kampung Batik, which includes a batik-making factory. Batik-making process is divided into two major divisions, the batik industry that uses stamp method and writing method (handmade batik). ${ }^{7}$ Both divisions have their own respective advantages. The stamp method is relatively easier because printed batik motifs have already used a stamp tool with a certain pattern. While in the process of handmade batik, the production process still uses traditional tools, called canting. The process of writing on batik is similar to painting, where the canvas is cloth and the brush is canting. Making process of artistic handmade batik takes longer time than stamp batik because of the process and the different levels of difficulty, so 
the price of handmade batik will also be more expensive than stamp batik. ${ }^{7}$ This long working duration often results in complaints of some craftsmen such as numbness in the palm of the hand or pain in the palm of the hand. To investigate the relationship between working period of batik craftsmen from Kampung Batik Laweyan with the incident of CTS, researchers conduct this research in Dr. Moewardi Regional General Hospital Surakarta.

\section{Methods}

The research was conducted at Neurology Clinic Dr. Moewardi Regional General Hospital Surakarta from April to June 2019 with a cross sectional design. The research subjects were determined by purposive sampling from the batik craftsmen of Kampung Batik Tulis Laweyan which met the inclusion and exclusion criteria until the analysis requirements was fulfilled. Research subjects who met the inclusion criteria signed an informed consent and underwent history taking, physical examination, and nerve conduction velocity test.

The inclusion criteria were batik craftsmen in Kampung Batik Tulis Laweyan both men and women, were able to read and write, and agreed to be the research participants (signed informed consent). While the exclusion criteria were the history of diabetes mellitus, dyslipidemia, trauma, tumors on the wrist, and pregnant craftswomen.

Data which had been collected was processed by the computer with a coding system. Spearman correlation analysis test was performed using SPSS Windows 22.0 program to analyze the data.

\section{Results}

The subjects of this study were 30 batik craftsmen examined at Neurology Clinic Dr. Moewardi Regional General Hospital Surakarta who met the inclusion and exclusion criteria. From the study sample obtained a number of 14 craftsmen (47\%) and 16 craftswomen (53\%). From the age range, the number of samples aged less than 40 years old was 14 craftsmen (47\%) while those aged over 40 years old were 16 craftsmen (53\%). The average of working period was 11.95 years with a span of 2 until 40 years, where craftsmen who have worked less than 5 years were $11(37 \%)$ while those who have worked more than 5 years were $19(63 \%)$. The demographic characteristics of the sample are shown in Table 1.

Patients were diagnosed with CTS from history taking and physical examination. ${ }^{2}$ This research was supported with electrophysiological examination or nerve conduction velocity examination as shown in Table 3 and 4.

Table 1. Demographic characteristics of the sample

\begin{tabular}{lc}
\hline \multicolumn{1}{c}{ Clinical Variable } & $\begin{array}{c}\text { Total Craftsmen } \\
(\mathbf{n = 3 0 )}\end{array}$ \\
\hline Gender & 14 \\
-Male & 16 \\
-Female & \\
Age & 16 \\
-More than 40 years old & 14 \\
-Less than 40 years old & \\
Working Period & 19 \\
-More than 5 years & 11 \\
-Less than 5 years & \\
\hline
\end{tabular}

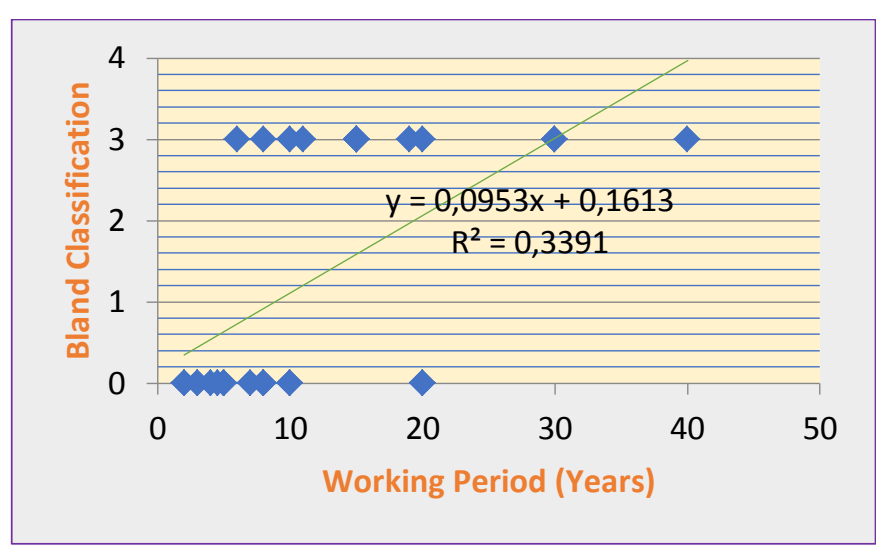

Figure 1. Spearman Correlation Curve

Table 2. Bland's Neurophysiological Grading Scale for Patients with $\mathrm{CTS}^{8}$

\begin{tabular}{|c|c|c|}
\hline Grade & & Nerve Conduction Findings \\
\hline 0 & Normal & $\begin{array}{l}\text { Normal motor and sensory conduction } \\
\text { studies }\end{array}$ \\
\hline 1 & Very mild & $\begin{array}{l}\text { CTS demonstrable only with most } \\
\text { sensitive tests }\end{array}$ \\
\hline 2 & Mild & $\begin{array}{l}\text { Sensory nerve conduction velocity slow } \\
\text { on finger/wrist measurement } \\
\text { Normal terminal motor latency }\end{array}$ \\
\hline 3 & Moderate & $\begin{array}{l}\text { Sensory potential preserved } \\
\text { Motor slowing; DML to ABP }<6.5 \mathrm{~ms} \\
\text { Sensory potentials absent }\end{array}$ \\
\hline 4 & Severe & $\begin{array}{l}\text { Motor potential preserved; DML to ABP } \\
<6.5 \mathrm{~ms}\end{array}$ \\
\hline 5 & $\begin{array}{l}\text { Very } \\
\text { severe }\end{array}$ & $\begin{array}{l}\text { Sensory potentials absent } \\
\text { DML to APB }>6.5 \mathrm{~ms}\end{array}$ \\
\hline 6 & $\begin{array}{l}\text { Extremely } \\
\text { severe }\end{array}$ & $\begin{array}{l}\text { Sensory and motor potentials effectively } \\
\text { unrecordable } \\
\text { Surface motor potential from } \mathrm{ABP}<0.2 \\
\mathrm{mV} \text { amplitude }\end{array}$ \\
\hline
\end{tabular}

DML indicates distal motor latency; APB indicates abductor pollicis brevis

Table 3. Results of motoric electrophysiological examination

\begin{tabular}{lcc}
\hline \multicolumn{1}{c}{ Variables Analyzed } & $\begin{array}{c}\text { Correlation } \\
\text { coefficient (r) }\end{array}$ & $\begin{array}{c}\text { Statistical } \\
\text { Significance (p) }\end{array}$ \\
\hline $\begin{array}{l}\text { Latency extension and } \\
\text { working period }\end{array}$ & 0.454 & 0.314 \\
$\begin{array}{l}\text { Decrease in amplitude } \\
\text { and working period }\end{array}$ & 0.247 & 0.172 \\
$\begin{array}{l}\text { Decrease in nerve } \\
\text { conduction velocity and } \\
\text { working period }\end{array}$ & 0.559 & 0.013 \\
\hline
\end{tabular}

Table 4. Results of sensory electrophysiological examination

\begin{tabular}{lcc}
\hline \multicolumn{1}{c}{ Variables Analyzed } & $\begin{array}{c}\text { Correlation } \\
\text { coefficient (r) }\end{array}$ & $\begin{array}{c}\text { Statistical } \\
\text { Significance (p) }\end{array}$ \\
\hline $\begin{array}{l}\text { Latency extension and } \\
\text { working period }\end{array}$ & 0.008 & 0.972 \\
$\begin{array}{l}\text { Decrease in amplitude } \\
\text { and working period }\end{array}$ & 0.004 & 0.946 \\
$\begin{array}{l}\text { Decrease in nerve } \\
\text { conduction velocity and } \\
\text { working period }\end{array}$ & 0.007 & 0.981 \\
\hline
\end{tabular}

The degree of CTS was classified using Bland's CTS scale (Table 2). The relationship between working period of batik craftsmen compared to the severity of CTS according to Bland's scale was statistically significant $(p=0.013)$. On the 
other hand, working period did not have significant relationship with the pain or numbness complaints of batik craftsmen $(\mathrm{p}=0.355)$.

\section{Discussion}

Working period of batik craftsmen in Kampung Batik Laweyan was related to the increased incidence of CTS. This research did not only look for clinical signs and symptoms but also use more objective measurement with electrophysiological examination. The research was conducted by measuring the nerve conduction velocity of batik craftsmen, both those who were with signs and symptoms of CTS and those who were not.

CTS is one of the most CTD often found in industrial workers who have repetitive movements such as tailors. ${ }^{9}$ In this research, we examined batik craftsmen who also did repetitive movement. Other studies suggest that CTS does not only affect industrial workers, but also affects other workers doing repetitive movement like using computer keyboards and mouse. ${ }^{4,9}$

In this study, latency could be interpreted as the time needed between the initial stimulus given to the onset or emergence of the response, and represented the flow of impulses along nerve fibers. ${ }^{2}$ The extension of average nerve latency on electrophysiological examination showed nerve conduction velocity slowing which might be caused by damage of nerve fibers. 5

The pathophysiology of nerve tissue damage in CTS is a combination between mechanical and ischemic factors. ${ }^{1,9}$ Mechanically, edema that occurs around the canal or compression will narrow the carpal tunnel which will cause obstruction of nerve fibers. Barriers toward the nerve movement in this canal will result in minor trauma to the nerve fibers which results in edema and irritation. ${ }^{1}$ Furthermore, scar adhesion that appears will increase local pressure and decrease nerve conductivity. Ischemicly, the compression that occurs will cause interference in intraneural microvascular, so the blood flow which vascularizes the nerve fibers becomes obstructed or a process of intraneural flow stasis happens. ${ }^{8}$

As the results shown in table 3, there was no statistically significant relationship between the value of the motoric amplitude and the working period. This phenomenon might occur because the type of lesion affecting the median motor nerve fibers was demyelinating lesion. Demyelinating lesions are lesions which affect the myelin sheath of the nerve without disturbing the axon of the nerve. ${ }^{1,9}$ The absence of a statistically significant relationship between amplitude and extension of motoric latency with the working period had also been stated in previous studies. ${ }^{2}$ This might also happen because not all samples in this study had motor symptoms. In addition, the normal values of amplitude and motoric latency in actual sample were not able to describe significant degree of lesion severity. ${ }^{2}$ The number of stimulated motor nerve fibers in both the mild-moderate and severe clinical symptoms was not related to the severity of the CTS symptoms that the patient complained of. ${ }^{1,5}$

Meanwhile, as shown in table 4, the extension of latency, amplitude, and nerve conduction velocity of the median sensory did not have a significant relationship with the working period. This might happen due to the abnormal distribution of abnormal Median Sensory Distal Latency (MSDL) data, which the number of undetectable MSDL values or equal to 0.00 milliseconds in the group with severe clinical symptoms. ${ }^{2,8}$ The MSDL value was not detected due to severe degree compression of the median nerve so nerve impulse delivery in sensory fibers could not occur. In addition, in samples with severe clinical symptoms, sometimes motor symptoms did not necessarily have to occur, but the loss of sensory sensibility alone is included in the severe classification. ${ }^{1,9}$ Besides, the electrophysiological examination only detected the process of demyelination and nerve axon damage in myelinated nerve fibers with large diameter, while the symptoms of CTS represented more damage to myelinated and unmyelinated nerve function with small diameter which were not assessed on the electrophysiological examination. ${ }^{1,5}$ The electrophysiological examination detects nerve conductivity in A fibers, but it is unable to detect nerve conductivity in $\mathrm{C}$ fibers because their diameter are too small. ${ }^{6}$

This study also showed that there was a statistically insignificant correlation between working period compared to complaints of batik craftsmen. This result might be caused by a high subjectivity factor in batik craftsmen who might not feel the CTS complaints that arose like tingling or numbness and only stated complaints after there was pain or burning sensation in the palm of the hand.

Since comorbidity that causes damage to median nerve in batik craftsmen is high, it is important to explore other factors that can worsen this damage. Hopefully, further research can explore and analyze other influential factors such as daily activities of batik craftsmen which may cause nerve damage.

This study had some bias that might not have been excluded. Exclusion criteria that only use the history taking process without the existence of more objective data such as radiological results. In addition, the number of sample available was still relatively small, so analysis based on sex could not be done. Further research may be able to include more sample since the number of batik craftsmen is indeed quite large.

\section{Conclusion}

Working period of batik craftsmen had a medium and positive relationship with the incidence of Carpal Tunnel Syndrome (CTS).

\section{Acknowledgement}

The researchers would like to thank to Sebelas Maret University; Dr. Moewardi Regional General Hospital, Surakarta, Central Java, Indonesia; and Forum Kampoeng Batik Tulis Laweyan, Surakarta, Central Java, Indonesia for facilitating this research.

\section{References}

1. Kurniawan SN, Husna M, Rasyid HA, Bilqis NE. The relationship of carpal tunnel syndrome clinical symptomps and electroneuromyography results in RSSA Malang. Malang Neurology Journal. 2016; 
2(1):24-29.

DOI: https://dx.doi.org/10.21776/ub.mnj.20 16.002.01.5

2. Chan L, Turner JA, Comstock BA, Levenson LM, Hollingworth W, Heagerty PJ, et al. The relationship between electrodiagnostic findings and patient symptoms and function in carpal tunnel syndrome. Arch Phys Med Rehabil Journal. 2007; 88:127-131.

DOI: https://doi.org/10.1016/j.apmr.2006.10.013

3. Setyawan H. Risk factors of carpal tunnel syndrome in food-packing workers Karanganyar. Kesmas: National Public Health Journal; 2017. 11(3):123-126.

DOI: https://dx.doi.org/10.21109/kesmas.v11i3.1185

4. International Labor Organization (ILO). The prevention occupational diseases. ISSA. Switzerland; 2013. 30-80

5. Hakim AL, Tjandra R. Hubungan tingkat keparahan gejala dan status fungsional pada pasien carpal tunnel syndrome diukur menggunakan carpal tunnel syndrome assessment. Jurnal Kedokteran Diponegoro; 2016. 5(3):174-187.

Avalable from: https://ejournal3.undip.ac.id/i ndex.php/medico/article/download/13082/12640

6. Kurniawan B, Siswi J, Yulianing S. Faktor risiko kejadian carpal tunnel syndrome (cts) pada wanita pemetik melati di Desa Karangcengis Purbalingga. Jurnal Promosi Kesehatan Indonesia; 2008. 3(1):5-8.

Avalable from:

https://ejournal.undip.ac.id/index.php/jpki/article/ view/2548/2258

7. Harlukinita D, Suroto W, Pramesti L. Pusat batik solo dengan pendekatan kearifan lokal studi kasus Kampung Batik Sondakan di Surakarta. Arsitektura; 2014. 12(1):28-31. Avalable from: https://jurnal.uns.ac.id/Arsitektura/article/download/157 $18 / 12652$

8. Malibary HM, Al-Najjar AT, Mohammed Yassen D, Almarzouki Abuhussain HA, Radhwi OO, Ridha Alfares Z. Clinical profile of carpal tunnel syndrome in a teaching hospital. Pak J Med Sci; 2013. 29(1):119121. DOI: https://dx.doi.org/10.12669/pjms.291.2946

9. Maghsoudipour M, Moghimi S, Deghaan F, Rahimpanah A. Associaton of occupational and nonoccupational risk factor with the prevalence of work related carpal tunnel syndrome. Journal Of Occupational Rehabilitation; 2008. 18:152-156. DOI: https://dx.doi.or g/10.1007/s10926-008-9125-4 